\title{
OPEN
}

Published online: 27 November 2019

\section{Author Correction: Silk physico- chemical variability and mechanical robustness facilitates intercontinental invasibility of a spider}

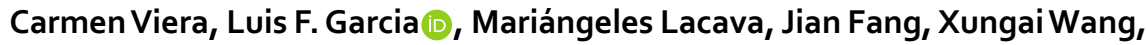 \\ Michael M. Kasumovic \& Sean J. Blamires (1)
}

Correction to: Scientific Reports https://doi.org/10.1038/s41598-019-49463-9, published online 13 September 2019

In the original version of this Article, Luis F. Garcia was incorrectly affiliated with 'Laboratorio Ecología del Comportamiento (IIBCE), Montevideo, Uruguay', 'Ciencias Biológicas PEDECIBA, Docente Grado 2 Entomología, CURE, Treinta y Tres, Uruguay’ and ‘Centro Universitario de Rivera, Universidad de la República, Rivera, Uruguay'.

The correct affiliation is listed below.

Centro Universitario Regional del Este, Sede Treinta y Tres. Universidad de la República. Treinta y Tres, Uruguay.

This error has now been corrected in the PDF and HTML versions of the Article and in the accompanying Supplementary Figure S1-S3 file.

(i) Open Access This article is licensed under a Creative Commons Attribution 4.0 International License, which permits use, sharing, adaptation, distribution and reproduction in any medium or format, as long as you give appropriate credit to the original author(s) and the source, provide a link to the Creative Commons license, and indicate if changes were made. The images or other third party material in this article are included in the article's Creative Commons license, unless indicated otherwise in a credit line to the material. If material is not included in the article's Creative Commons license and your intended use is not permitted by statutory regulation or exceeds the permitted use, you will need to obtain permission directly from the copyright holder. To view a copy of this license, visit http://creativecommons.org/licenses/by/4.0/.

(C) The Author(s) 2019 